PROGRAM EVALUATION

\title{
Home delivery of an injury prevention kit for children in four French cities: a controlled randomized trial
}

\author{
M Sznajder, S Leduc, M P Janvrin, M H Bonnin, P Aegerter, F Baudier, B Chevallier
}

Injury Prevention 2003;9:261-265

\begin{abstract}
Objectives: Home delivery of counselling and safety devices to prevent child injuries could help parents to adopt safe behaviour. The aim of this study was to test a safety kit designed and used in Quebec (Canada).

Design and subjects: One hundred families from four towns in the Paris suburbs were visited at home by nurses or doctors when their child reached 6-9 months. Selection criteria were: primipara, medical problem, psychological, and/or socioeconomic difficulties.

Interventions: During the first visit, 50 families (group 1) received counselling and a kit including preventive devices and pamphlets about indoor injuries and ways to avoid them. The other 50 families (group 2) received counselling but not the kit. A second home visit was made 6-8 weeks later.

Main outcome measures: The number of safety improvements was calculated 6-8 weeks after a first home visit. Perceived usefulness of the kit was collected from families and from interviewers.

Results: Between the first and the second visits, safety improvement was significantly higher in the group with the kit. This was mainly related to the risk of fall $(p<0.02)$, fire and burns $(p<0.001)$, poisoning $(p<0.01)$, and suffocation $(p<0.001)$. For improvement related to devices provided in the kit, the difference between the groups was significant: $64.4 \%$ improvement in group 1 versus $41.2 \%$ in group 2 ( $p<0.01)$. The relative risk (RR) of safety improvement between groups was 1.56 (95\% confidence interval (Cl) 1.35 to 1.80). Even for improvements not related to the kit the difference remained significant: $31.2 \%$ in group 1 versus $20.2 \%$ in group $2(p<0.05) ; R R=1.54(95 \% \mathrm{Cl} 1.22$ to 1.93$)$. Conclusion: Routine home visits by social services offer a good opportunity to tackle child injury prevention. Free delivery of prevention kits and counselling allow families to modify their behaviour and homes so as to reduce risks.
\end{abstract}

See end of article for authors' affiliations

Correspondence to: Dr Marc S Sznajder Hopital Ambroise Paré, Service de Santé Publique et Information Médicale, 9 avenue Charles de Gaulle, 92100 , Boulogne, France; marc.sznajder@ apr.ap-hop-paris.fr
$\mathrm{D}$ omestic injuries remain a major cause of morbidity and mortality among young children. ${ }^{1-4}$ However, since the early 1980s in France, non-traffic accident related mortality has been reduced by as much as $80 \%{ }^{5}$ This is probably due to complementary legal and educational measures such as medicine packaging and information campaigns conducted by public departments-for example, the Ministries of Health, Treasury, and Social Security.

Fieldwork increases the value of prevention in a pragmatic and continuous way, particularly in keeping with the general pattern of safe community programs. ${ }^{6-9}$ It appears cost effective in low socioeconomic status families who are more vulnerable to injuries and have fewer financial resources for prevention. ${ }^{1011}$ Prevention based only upon education is inefficient in this context. ${ }^{12-14}$ Free or discounted preventive measures are warranted given the large gradient and increasing trend in injury related deaths according to social class in recent years. ${ }^{15} 16$

The aim of this study was to test the effectiveness of free preventive devices and counselling for low socioeconomic status families. This reflects both a nationwide program of injury prevention by the National Health Insurance and the French committee for health education ${ }^{17}$ and the France-Quebec prevention network. A preventive kit developed in Quebec ${ }^{18}$ was adapted and assessed.

\section{SUBJECTS AND METHODS}

The study was carried out between October 2000 and April 2001 in the Department of Hauts-de-Seine near Paris. This region was chosen because of increased injury prevention efforts, particularly in the second largest town of Boulogne (107000 people), where a safe community program was started in $1997 .{ }^{19} 20$
One hundred families from four towns (BoulogneBillancourt, Chaville, Sèvres, and Ville d'Avray), were selected by Mother and Child Protection services (PMI), a free nationwide health organisation. PMI's usual criteria for services were used and included primipara, medical, psychological, and/or socioeconomic difficulties. Demographic data for these towns are summarized in table 1.

Families were randomized into two groups of 50; one family was lost to follow up in group 1. Group 1 received counselling, two pamphlets about domestic injuries and methods of prevention, emergency call numbers, and a safety kit. The kit included cupboard and drawer latches, door handle covers, table protection corners, electric outlet covers, a non-skid bathtub mat, a smoke detector, and a phone sticker with the number of the poison control centre.

Group 2 received counselling and pamphlets but did not receive the kit. Visits were conducted by health professionals (25 doctors, nurses, or auxiliary nurses) who received the same instructions for home visits and data collection. Qualitative and quantitative data, that is, process and impact, were collected by questionnaire and interview.

The first home visit occurred when a child reached the age of 6-9 months. Information about social status, highest school level of the respondent (generally the mother), physical environment at home, and safety behaviours were collected during this visit. A second visit was performed 6-8 weeks later by the same health professional.

Safety behaviour was measured at the first and second visits using a closed response questionnaire. The safe or dangerous

Abbreviations: $\mathrm{Cl}$, confidence interval; $\mathrm{PMI}$, Mother and Child Protection (service); RR, relative risk 
Table 1 Demographic data in the four towns of the study (source: last 1999 national census)

\begin{tabular}{lllllll}
\hline Towns & $\begin{array}{l}\text { Total } \\
\text { population }\end{array}$ & $\begin{array}{l}\text { Population } \\
\text { 0-19 years } \\
\text { (\%) }\end{array}$ & $\begin{array}{l}\text { Unemployment } \\
\text { (\%) }\end{array}$ & $\begin{array}{l}\text { Families' } \\
\text { mean size }\end{array}$ & $\begin{array}{l}\text { House } \\
\text { (dwelling } \\
\text { type) (\%) }\end{array}$ & $\begin{array}{l}\text { Property } \\
\text { owner (\%) }\end{array}$ \\
\hline Boulogne & 106316 & 20.0 & 9.3 & 2.0 & 2.7 & 37.9 \\
Chaville & 38983 & 24.4 & 6.7 & 2.4 & 26.1 & 54.5 \\
Sévres & 22555 & 25.5 & 7.9 & 2.4 & 20.9 & 46.2 \\
Ville d'Avray & 11393 & 26.9 & 6.8 & 2.5 & 15.1 & 51.7 \\
Metropolitan France & 58520688 & 24.6 & 12.9 & 2.4 & 55.9 & 54.9 \\
\hline
\end{tabular}

character of each home situation was defined in an inventory at the end of the questionnaire. The definition of safe behaviours was related to appropriate answers to the questions in table 5. For instance: "Do you use electric outlet covers? (yes); Are medicines stored in locked or out-of-reach locations? (yes); Are there stray wires that might cause people to trip? (no) ...".

During the second visit, improvement in safe behaviour was assessed by increased use of safety devices. Three conditions were used in the analyses: first, safety improvement related to each type of home injury regardless of relationship to the kit; second, safety improvement for risks preventable by devices in the kit; and third, safety improvement for risks not related to devices in the kit.

Global satisfaction with the intervention was assessed among families through an open questionnaire during the second visit and focus groups assessed the global benefit of the kit, negative and positive points, and receptivity of the families.

Filemaker Pro software (version 4.1) was used for data capture. Statistical analyses were performed by SPSS software (version 8.0). The $\chi^{2}$ test was used for comparison of qualitative data and the Fisher's exact test was used in the case of small sized samples. Quantitative data were compared by Student's $t$ test. A p value less than $5 \%$ was considered as significant.

\section{RESULTS}

\section{Quantitative evaluation in all families}

The two groups were comparable in age, gender, and employment of the respondent, type of family, type of dwelling, number of children in the family, and highest school level (tables 1 and 2). Between the first and the second visit, the percentage of safety improvement was significantly higher in the group with the kit (group 1). Comparisons between the two groups and between the first and the second visits were analysed for each type of risk (table 3 ). Improvement was related to the risk of falls $(\mathrm{p}<0.02)$, fire and burns $(\mathrm{p}<0.001)$, poisoning $(\mathrm{p}<0.01)$, and suffocation $(\mathrm{p}<0.001)$.

The use of devices provided in the kit was significantly different between the two groups: $64.4 \%$ safety improvement in group 1 versus $41.2 \%$ in group $2(\mathrm{p}<0.01)$ (table 4$)$. The relative risk (RR) of safety changes between groups was 1.56 (95\% confidence interval (CI) 1.35 to 1.80). Improvements were also observed for changes unrelated to the devices provided: $31.2 \%$ in group 1 versus $20.2 \%$ in group $2(p<0.05)$ (table 5$)$. Several categories had higher improvement in group 2, yet the RR between groups was 1.54 (95\% CI 1.22 to 1.93 ).

\section{Quantitative evaluation in particular situations}

In single parent families, there was a significant difference between the groups for use of devices provided in the kit: $90.0 \%$ in group 1 versus $44.4 \%$ in group $2(p<0.007)$. No difference was noted for devices not provided. There also was a significant difference in use of provided devices for families

\begin{tabular}{|c|c|c|c|}
\hline & $\begin{array}{l}\text { Group with kit } \\
(n=49)(\%)\end{array}$ & $\begin{array}{l}\text { Group without } \\
\text { kit }(n=50)(\%)\end{array}$ & $\mathrm{p}$ Value \\
\hline \multicolumn{4}{|l|}{ Respondent } \\
\hline Father & 8.2 & 2.0 & \multirow[t]{3}{*}{0.58} \\
\hline Mother & 83.7 & 90.0 & \\
\hline Two parents & 8.2 & 8.0 & \\
\hline \multicolumn{4}{|l|}{ Family type } \\
\hline One parent & 14.3 & 12.0 & \multirow[t]{4}{*}{0.17} \\
\hline Two parents & 83.7 & 80.0 & \\
\hline Reconstituted & 0.0 & 8.0 & \\
\hline Unknown & 2.0 & 0.0 & \\
\hline \multicolumn{4}{|l|}{ Dwelling type } \\
\hline House & 6.1 & 6.0 & \multirow[t]{4}{*}{0.60} \\
\hline Block of flats & 91.8 & 92 & \\
\hline Temporary & 2.0 & 0.0 & \\
\hline Unknown & 0.0 & 2.0 & \\
\hline \multicolumn{4}{|l|}{ School level } \\
\hline Primary school & 8.2 & 4.0 & \multirow{5}{*}{0.83} \\
\hline Secondary school & 22.4 & 24.0 & \\
\hline Grammar school & 14.3 & 16.0 & \\
\hline University & 49.0 & 54.0 & \\
\hline Unknown & 6.1 & 2.0 & \\
\hline \multicolumn{4}{|l|}{ Job situation } \\
\hline Salaried job & 63.3 & 58.0 & \multirow[t]{5}{*}{0.62} \\
\hline Independent & 0.0 & 2.0 & \\
\hline Training & 2.0 & 0.0 & \\
\hline Jobless & 4.0 & 2.0 & \\
\hline Home & 30.7 & 32.0 & \\
\hline \multicolumn{4}{|c|}{ Followed by PMI services } \\
\hline Yes & 32.7 & 38.0 & \multirow[t]{3}{*}{0.74} \\
\hline No & 63.3 & 60.0 & \\
\hline Unknown & 4.0 & 2.0 & \\
\hline $\begin{array}{l}\text { Mean (SD) age of } \\
\text { respondent }\end{array}$ & $32.4(5.1)$ & $32.3(5.9)$ & 0.91 \\
\hline $\begin{array}{l}\text { Mean (SD) number of } \\
\text { children }\end{array}$ & $1.7(0.8)$ & $1.9(1.0)$ & 0.22 \\
\hline Percent primipara & 49 & 42 & 0.80 \\
\hline $\begin{array}{l}\text { Mean (SD) age of } \\
\text { children (years) }\end{array}$ & $3.9(4.4)$ & $4.5(4.2)$ & 0.48 \\
\hline
\end{tabular}

where the respondents' level of education was low (no university studies): $61.5 \%$ in group 1 versus $36.5 \%$ in group 2 $(\mathrm{p}<0.01)$.

In families with at least two children (25 in group 1, 29 in group 2), no significant difference was observed between groups for any type of prevented risk.

\section{Qualitative evaluation}

The receptivity and interest of families was considered good. At the second visit, some parents had made safety improvements in areas not addressed at the first visit, such as curtain strings or furniture under windows. More than nine in 10 families declared they would participate if such a program was implemented again. They also claimed considerable need for training, particularly concerning child injury morbidity, risks according to stage of child development, and means of 
Table 3 Observed safety improvements between visits by groups and type of injury

\begin{tabular}{|c|c|c|c|c|c|}
\hline \multirow[b]{2}{*}{ Injury type } & \multicolumn{2}{|c|}{ Group with kit } & \multicolumn{2}{|c|}{ Group without kit } & \multirow[b]{2}{*}{$\mathrm{p}$ Value } \\
\hline & $\mathrm{V} 2 / \mathrm{V} 1^{*}$ & $\begin{array}{l}\text { Improvement } \\
\text { between the two } \\
\text { visits (\%) }\end{array}$ & $\mathrm{V} 2 / \mathrm{V} 1$ & $\begin{array}{l}\text { Improvement } \\
\text { between the two } \\
\text { visits (\%) }\end{array}$ & \\
\hline Falls & $65 / 144$ & 45.1 & $41 / 133$ & 30.8 & $<0.02$ \\
\hline Fire & $53 / 161$ & 32.9 & $24 / 163$ & 14.7 & $<0.001$ \\
\hline Poisoning & $76 / 116$ & 65.5 & $46 / 98$ & 46.9 & $<0.01$ \\
\hline Suffocation & $27 / 49$ & 55.1 & $11 / 50$ & 22.0 & $<0.001$ \\
\hline Wounds & $23 / 48$ & 47.9 & $25 / 55$ & 45.5 & 0.95 \\
\hline
\end{tabular}

*V1, number of cases where a high risk situation was noted at the first visit; V2, number of cases where a safety change was observed at the second visit.

Table 4 Reported improvements between visits by groups with and without kit related to kit contents

\begin{tabular}{|c|c|c|}
\hline \multirow[b]{2}{*}{ Questions } & \multicolumn{2}{|c|}{ Improvement between the two visits (\%) } \\
\hline & $\begin{array}{l}\text { Group with the kit } \\
(\mathrm{V} 2 / \mathrm{V} 1)^{*}\end{array}$ & $\begin{array}{l}\text { Group without the kit } \\
(\mathrm{V} 2 / \mathrm{V} 1)^{*}\end{array}$ \\
\hline $\begin{array}{l}\text { 1. How many smoke detectors have been installed } \\
\text { efficiently? (that is, how many families changed from } \\
\text { none to one detector at least?) }\end{array}$ & $26 / 46$ & $5 / 49$ \\
\hline 2. Do you use electric outlet covers? & $16 / 25$ & $11 / 24$ \\
\hline $\begin{array}{l}\text { 3. Are medicines stored in locked or out-of-reach } \\
\text { locations? }\end{array}$ & $13 / 15$ & $8 / 13$ \\
\hline $\begin{array}{l}\text { 4. Is alcohol stored in locked or out-of-reach } \\
\text { locations? }\end{array}$ & $10 / 18$ & $2 / 16$ \\
\hline $\begin{array}{l}\text { 5. Are beauty products (bath oil, shampoos, } \\
\text { aftershave lotions) stored in locked or out-of-reach } \\
\text { locations? }\end{array}$ & $21 / 32$ & $13 / 25$ \\
\hline $\begin{array}{l}\text { 6. Are cleaning products (dishwashing detergent, } \\
\text { bleach, oven cleaner) stored in locked or } \\
\text { out-of-reach locations? }\end{array}$ & $20 / 28$ & $17 / 26$ \\
\hline $\begin{array}{l}\text { 7. Are home maintenance products (weed killers, } \\
\text { insecticides, kerosene) stored in locked or } \\
\text { out-of-reach locations? }\end{array}$ & $10 / 14$ & $6 / 17$ \\
\hline $\begin{array}{l}\text { 8. Are sharp pointed table corners covered with } \\
\text { protection devices? }\end{array}$ & $25 / 30$ & $13 / 27$ \\
\hline $\begin{array}{l}\text { 9. Do you have non-skid strips or a non-skid mat in } \\
\text { your bathtub? }\end{array}$ & $11 / 28$ & $19 / 31$ \\
\hline Totalt & $152 / 236(64.4 \%)$ & $94 / 228(41.2 \%)$ \\
\hline
\end{tabular}

prevention. Training in optimal use of the kit and what to do in case of emergency were sought by most parents.

Focus group meetings with health professionals were relevant for both process and impact assessment. Kit delivery at home was generally considered as propitious for discussion and for the effectiveness of the intervention. It heightened awareness of potential domestic dangers and prompted reflection on safety. The questionnaire was also positively perceived and was considered as a vehicle to provide information.

Some devices required assistance from health professionals for installation and use, particularly those requiring a screwdriver. This happened only during the second visit and had no influence on results. The most appreciated devices were door handle covers, electric outlet covers, cupboard and drawer latches, pamphlets, and emergency phone numbers. Devices that were rarely used or unsuited to the home included a screw hook, an inflated tap cover, and a refrigerator closing strip. Table corner covers and a universal door latch for electrical appliances were judged as too fragile. Health professionals proposed the inclusion of new devices such as window chains and curtain string rollers. All health professionals expressed the desire for the program to continue so they could incorporate it into their daily practice

\section{DISCUSSION}

Four minimal conditions, identified in the literature, are required to guarantee the success of such a project:

1. Kit delivery and counselling must be done in the home.

2. Safety devices must be free and easy to use.

3. Families may need help to install devices.

4. Several home visits must be planned for follow through.

Repeated home visits and subsidized safety devices promote a "therapeutic alliance" especially for groups at high risk of injury. ${ }^{21}$ The present study was conceived in this spirit following the example of the Quebec study. City selection was related to practical considerations for project implementation with adequate staff. Family selection based on PMI recruitment criteria theoretically targeted low socioeconomic populations. However, nearly half of the families in both groups had a high education level, two thirds had a wage earning job, and the unemployment rate was quite low. But other criteria for PMI recruitment, such as psychological difficulties or isolation, are also related to home injury risk. Thus our pilot study included several differently defined high risk groups.

A possible difficulty in the interpretation of results is the use of global tests performed on a sum of questions. This unweighted sum of risk situations may be questionable. 


\begin{tabular}{|c|c|c|}
\hline \multicolumn{3}{|l|}{$\begin{array}{l}\text { Table } 5 \\
\text { contents }\end{array}$} \\
\hline \multirow[b]{2}{*}{ Questions } & \multicolumn{2}{|c|}{ Improvement between the two visits (\%) } \\
\hline & $\begin{array}{l}\text { Group with kit } \\
(\mathrm{V} 2 / \mathrm{V} 1)^{*}\end{array}$ & $\begin{array}{l}\text { Group without kit } \\
(\mathrm{V} 2 / \mathrm{V} 1)^{*}\end{array}$ \\
\hline $\begin{array}{l}\text { 1. Are stair gates present at the top or bottom of } \\
\text { staircases? }\end{array}$ & $0 / 2$ & $1 / 6$ \\
\hline 2. Is there a walker in the home and is it being used? & $0 / 19$ & $7 / 21$ \\
\hline 3. Are carpets and rugs properly secured? & $3 / 23$ & $2 / 27$ \\
\hline 4. Is the highchair safe? & $12 / 17$ & $5 / 12$ \\
\hline $\begin{array}{l}\text { 5. Are there stray wires that might cause people to } \\
\text { trip? }\end{array}$ & $8 / 14$ & $6 / 18$ \\
\hline $\begin{array}{l}\text { 6. Is there a risk of fall out of the balcony or the } \\
\text { window? }\end{array}$ & $12 / 21$ & $1 / 18$ \\
\hline $\begin{array}{l}\text { 7. Is there an operating and easily accessible fire } \\
\text { extinguisher? }\end{array}$ & $2 / 39$ & $2 / 36$ \\
\hline 8. Are matches and lighters out of children's reach? & $9 / 9$ & $3 / 7$ \\
\hline $\begin{array}{l}\text { 9. Has the hot water heater been set so that hot water } \\
\text { will not scald a young child? }\end{array}$ & $0 / 42$ & $3 / 47$ \\
\hline 10. Are there toxic plants at home? & $2 / 9$ & $0 / 1$ \\
\hline 11. Is the child's bed safe? & $9 / 9$ & $5 / 10$ \\
\hline 12. Is the playpen safe? & $1 / 3$ & $2 / 6$ \\
\hline $\begin{array}{l}\text { 13. Are small objects on which a child could choke } \\
\text { (paper clips, pins, coins, etc) out-of-reach in a safe } \\
\text { location? }\end{array}$ & $1 / 12$ & $1 / 14$ \\
\hline $\begin{array}{l}\text { 14. Are foods that could cause asphyxiation (flour, } \\
\text { dough, etc) out-of-reach in a safe location? }\end{array}$ & $5 / 7$ & $1 / 6$ \\
\hline $\begin{array}{l}\text { 15. Are curtain and blind cord reels in out-of-reach } \\
\text { positions? }\end{array}$ & $13 / 19$ & $4 / 15$ \\
\hline 16. Does your child wear a helmet when bicycling? & $5 / 18$ & $12 / 28$ \\
\hline Totalt & $82 / 263(31.2 \%)$ & $55 / / 272(20.2 \%)$ \\
\hline
\end{tabular}

Additionally, some families are probably more at risk than others, and some risks are linked. But statistical tests performed for each question individually lack power so comparisons are rarely significant. Since the aim of the study was to test the impact of the kit and its effect on safety behaviours as a whole, we believe global tests are relevant.

Other studies have also shown positive results for a combined approach of free home counselling and safety devices. Six year follow up data of a fire prevention program in Oklahoma City (USA) indicate an $81 \%$ reduction in fire related injuries among the targeted population versus $7 \%$ in the rest of the town. ${ }^{22}$

Data on the financial aspects of this kind of intervention are rare. The same program among low socioeconomic groups in London is being assessed. ${ }^{23} \mathrm{~A}$ cost effectiveness analysis of the preventive impact of home visits in a multicentre survey in Canada indicates a savings of 372 Canadian dollars per avoided injury. ${ }^{24}$

Owning prevention tools in not always sufficient. The adoption of safety conscious behaviour, even among higher socioeconomic groups, is not automatic. ${ }^{25}$ Home visits, free safety devices, and a pedagogic approach are all needed. ${ }^{26}$

A recent review of 22 randomized studies targeting child safety practices indicates that most efficient interventions are those combining health education, behaviour change strategies, and "reinforcement". ${ }^{27}$

Our results reflect the same trends as those found in Quebec: the relative risk between groups in terms of safety changes related to provided devices was 1.86 in Quebec and 1.56 in France. Concerning devices not provided in the kit, the relative risk was significantly different from 1 , but with a larger difference (2.55 in Quebec, 1.54 in France). However four years separated the control group's visits and those of the experimental group in Quebec.

In situations supposedly of high risk-single parent families, low level of education-kit safety device results are superimposed on the whole sample, resulting in a highly significant difference between groups. This is not the case for devices not provided and we conclude that free safety devices are probably crucial for implementation of home safety changes. We also observed that the impact of the kit was lower for families with at least two children, probably because parents were already better informed. But the sample is small and the results may be difficult to extrapolate. As in the study by Leduc, ${ }^{18}$ we observed in the experimental group a "multiplying effect" of additional safety improvements not related to the provided devices and not explicitly discussed at the first visit. It appears the safety kit increases the global sensitivity of families to prevention.

Sometimes health professionals installed or helped families to install devices during the second visit. This a reality in the field and must be taken into account in the planning of an effective program. An additional reality is that visits to some dangerous dwellings often prompted the installation of a smoke detector.

The dangerous or safe nature of each home situation was defined at the end of the questionnaire; this may reduce the risk of interviewer bias linked to both subjective assessment of items and knowledge of group assignment (control or experimental).

The success of this region-wide pilot study was probably facilitated by previous injury awareness campaigns and by the multidisciplinary safe community program in BoulogneBillancourt. ${ }^{19} 20$ To promote this type of intervention on a large scale requires support at the local level. A cartographic analysis of injuries, similar to that of Boulogne-Billancourt (to be published), may also facilitate the targeting of families in high risk areas.

While it is probable that this type of program results in injury reduction, we did not measure its effect on injury occurrence. Before nationwide implementation, the impact of the program must be assessed in terms of reduced morbidity. 


\section{Key points}

- The aim of the present study was to adapt and test in France a safety kit designed and used in the Bas-Saint-Laurent region (Quebec, Canada), to implement it in a pilot area, and to assess its effectiveness before a large scale use.

- These first results indicate that routine home visits performed by PMI services constitute a good opportunity to tackle the question of child injury prevention. Free delivery of safety kits, accompanied by simple counselling, often enable families to change their behaviour and to implement safety measures in their home, even for risks not prevented by the kit devices.

- This multicentre international study contributed to validate this tool of prevention and its method of delivery (subsidizing, home visits, adapted devices), for a large scale use.

A cost outcome analysis must also be conducted in addition to addressing ethical issues concerning populations who do not receive the kit.

\section{Authors' affiliations}

M Sznajder, Department of Pediatrics and Department of Public Health and Medical Informatics, Ambroise Paré Hospital, Boulogne, France

S Leduc, National Public Health Institute of Quebec, Rimouski, Québec, Canada

M P Janvrin, French Committee for Health Education, Vanves, France M H Bonnin, Mother and Child Protection Service, Issy les Moulineaux, France

P Aegerter, Department of Public Health and Medical Informatics, Ambroise Paré Hospital, Boulogne, France

F Baudier, National Health Insurance, Paris, France

B Chevallier, Department of Pediatrics, Ambroise Paré Hospital,

Boulogne, France

\section{REFERENCES}

1 Tursz A, Lelong N, Crost M. Home accidents to children under 2 years of age. Paediatr Perinat Epidemiol 1990;4:408-21.

2 Lavaud J, Chouakri $O$. Les accidents domestiques chez l'enfant. Rean Med Urg 1993;9:1 10-8.

3 Mercier C, Blond M. Epidemiological survey of childhood burn injuries in France. Burns 1996;22:29-34.

4 Capon-Degardin N, Martinot-Duquennoy V, Lesage-Maillard V, et al. Facial burns in children. Ann Chir Plast Esthet 2001;46:190-5.

5 Inserm. Causes médicales des décès. Résultats définitifs France. Liste simplifiée S9. Paris: Inserm/SC 8, 1999.

6 World Health Organization. Manifest for Safe Communities. Proceedings of the 1st World Conference on Accident and Injury Prevention. Stockholm 1989. Geneva: WHO.

7 Sundström M, Svanström L. Criteria for the safe community network. Stockholm: WHO Collaborating Center Karolinska Institute, 1996.

8 Klassen TP, MacKay M, Moher D, et al. Community-based injury prevention interventions. The Future of Children 2000;10:83-110.

9 Bablouzian L, Freedman ES, Wolski KE, et al. Evaluation of a community based childhood injury prevention program. Inj Prev 1997:3:14-6.

10 Masson F, Saves M, Salmi LR, et al. Injuries in a problematic socioeconomic context: a population-based study in Reunion, Indian Ocean, 1993-1994. GEAR. Groupement d'Etude sur les Accidents à la Réunion. Int J Epidemiol 1997;26: 1033-40.

11 Miller TR, Levy DT. Cost-outcome analysis in injury prevention and control. Eighty-four recent estimates for the United States. Med Care 2000;38:562-82

12 Dershewitz RA, Williamson JW. Prevention of childhood household injuries: a controlled clinical trial. Am J Public Health 1977;67: 1 148-53.

13 Colver AF, Hutchinson PJ, Judson EC. Promoting children's home safety. BM 1982;285: $1177-80$

14 Dowswell T, Towner EM, Simpson G, et al. Preventing childhood unintentional injuries - what works? A literature review. Inj Prev 1996;2:140-9.

15 Roberts I, Power C. Does the decline in child injury mortality vary by social class? A comparison of class specific mortality in 1981 and 1991 BM 1996;313:784-6.

16 Downsell T, Towner E. Social deprivation and the prevention of unintentional injury in childhood: a systematic review. Health Educ Res 2002:17:221-37.

17 Baudier F, Janvrin MP. Prévention des accidents de la vie domestique. Le guide des programmes coopératifs. Vanves: Éditions du CFES, 1995 120 .

18 Leduc $\mathrm{S}$. Evaluation d'une trousse de prévention des traumatismes à domicile survenant à de jeunes enfants. Direction de la santé publique, de la planification et de l'évaluation. Québec: Régie régionale de la santé et des services sociaux du Bas-Saint-Laurent, 1999.

19 Chevallier B, Bruneau C, Leroux G, et al. Approche communautaire de la prévention des accidents de l'enfant. Concept et application pratique: le programme de la ville de Boulogne-Billancourt 1998-2002. Ann Pédiatr (Paris) 1999;46:330-6.

20 Sznajder M, Chevallier B, Leroux G, et al. Fréquence des accidents de I'enfant: premiers résultats de l'Observatoire de Boulogne-Billancourt. Rev Epidém et Santé Publ 2001:49:125-39.

21 Roberts I, Kramer MS, Suissa S. Does home visiting prevent childhood injury? A systematic review of randomised controlled trials. BM 1996;312:29-33

22 Mallonee S. Evaluating Injury Prevention Programs: The Oklahoma City Smoke Alarm Project. The Future of Children 2000;10:164-74.

23 DiGuiseppi C, Slater S, Roberts I, et al. The "Let's get Alarmed!" initiative: a smoke alarm giveaway program. Inj Prev 1999;5:177-82.

24 King WJ, Klassen TP, LeBlanc J, et al. The effectiveness of a home visit to prevent childhood injury. Pediatrics $2001 ; 108: 382-8$

25 Hapgood R, Kendrick D, Marsh P. How well do socio-demographic characteristics explain variation in childhood safety practices ? J Public Health Med 2000;22:307-11

26 Pless B. The scientific basis of childhood injury prevention: a review of the medical literature. London, UK: Child Accident Prevention Trust, 1993.

27 DiGuiseppi C, Roberts I. Individual-level injury prevention strategies in the clinical setting. The Future of Children 2000;10:53-82.

\section{COMMENTARY}

\section{Critique and recommendations (evaluation of evaluations)}

The randomized controlled trial is considered the "gold standard" design for evaluating the effectiveness of an intervention. Therefore, Sznajder and colleagues should be congratulated for using this design in their evaluation of a home injury prevention kit. The study randomized parents to two groups; the intervention group received in-home counselling, educational pamphlets, emergency telephone numbers, and a safety kit (consisting of cupboard and drawer latches, door handle covers, table protection corners, electric outlet covers, a non-skid bathtub mat, a smoke detector, and the poison control center number). The control group received counselling, educational pamphlets, and emergency telephone numbers only.

\section{Critique}

The main threat to the internal validity of the study was the lack of blinding of study personnel. The health professional who delivered the injury prevention intervention to the family also collected baseline information and follow up data 6-8 weeks later. This lack of blinding may have influenced the delivery of the intervention and the validity of the outcome data. For example, while all health professionals "received the same instructions for home visits", focus group data showed that the safety kit was considered "propitious for discussion and for the effectiveness of the intervention" by the health professionals. In other words, the intervention group may have received safety counselling that was qualitatively and quantitatively different from the counselling received by the control group. In addition, baseline and follow up data on safety behaviors were based on parental responses to a questionnaire administered in-person by the health professional who delivered the intervention.

\section{Recommendations}

Given that these data were based on self report rather than direct observation, the data would have been more convincing had the data collection process been blind. In other words, information bias would have been minimized if the interviewer collecting baseline and outcome data had been unaware of the group allocation (intervention or control) of the parent. Although blinding is not always possible, in this instance it seems it would have been entirely feasible.

\section{Macarthur}

Hospital for Sick Children, Toronto, Ontario, Canada; colin.macarthur@sickkids.ca 